\title{
再帰表現 “自己”について
}

\section{呼 美蘭}

今年来, 汉语反身代词的研究是国际理论语言学界的一个热点. 汉语 的反身代词主要有两种形式: 简单形式反身代词 “自己” 和复合形式反身 代词“代词十自己”(“他自己”“我自己”等). 迄今为止许多学者们由Chomsky 的约束理论来研究汉语的反身代词，认为汉语的复合形式反身代词与英语 的反身代词 “代词+self/selves” ( 如himself, myself, herself 等 ) 有相近的性质。 至于简单形式反身代词 “自己” 学者们已提出了不尽相同的句法理论, 目 前还没有很好的句法分析法，尚未充分说明汉语反身代词的特点. 笔者认 为汉语反身代词的最终解释不可能完全由句法包㩍，应该从语用或语义等 另外角度进行考察.

本文试图通过一些小说里的资料，对汉语反身代词，日语反身代词(自 分），英语反身代词加以分析，探讨三者在语义上、语用上的共同点，捕捉 汉语反身代词的特性.

0. はじめに

問題提起

1. 中国語・日本語・英語の再㷌表現

2. “自己” の敬語性

3. 意識の想定

4. 視点と “自己”

3. まとめ

\section{0. はじめに}

従来まで中国語の再帰代名詞については、変形文法の立場から研究され たものが多かった。しかしながら、中国語の再㷌代名詞の説明には、統語 構造による考察だけでは不十分で、他の観点からの検討も必要ではないか と考える。本稿は中国語・英語・日本語の再帰代名詞を比較対照し、中国 語の再帰代名詞の機能を意味論・語用論的な観点から明らかにする。 


\section{問題提起}

外国語として中国語を学んでいる者が、小説などを読み進むうち、学校 で学んだ文法だけでは、理解しにくい文章に出合う事がある。つまり日常 の会話では生起し得ない文 (unspeakable sentense) である。以下に挙げる 文章は小説の書き出し部分で、この小説は一人称“我”による語りの形式 をとっている。一人称語りの形式をとる小説は、しばしば見られる。しか しながらこの小説の場合は、作者と物語の語り手である主人公との関係が、 やや複雑な構成となっている。まずは以下文中の人称代名詞の使用状況に 注目されたい。

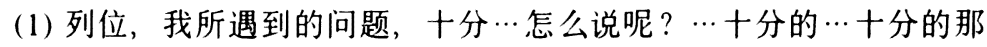
个! 很麻烦, 很严重, 使我恼差……但是又没法儿成怒。因为我根本 不知道该向谁去怒。(中略)

如果一个人，人缘儿挺好的一个人，日子过得挺顺心的一个人，某 一天无意中发现, 发现自己 …可能正在长出着尾巴, 不, 不是他妈的 什么可能不可能, 竟是一个无可争辩的事实一因为它, 我指的当然 是尾巴, 从我骶骨那儿长出着的尾巴, 已经六寸多长了, 那么他, 也就是我, 究竟该拿 自己怎么办呢? (尾巴)

一人称語りの形式をとる小説は、特定の登場人物の目を通して描かれる のが、一般的な手法である。すなわち特定の人物の視点を通じ、作品中の さまざまな出来事が描写される。物語の進行は、おおむねこの特定の人物 に委ねられ、情報はこの人物の目を通し読者に提示される。上に挙げた作 品の主人公“我” の職業は小説家という設定で、主人公であると同時に、 物語の語り手である。この作品では、時に語り手の“我”が作中人物の“我” から独立し、一人歩きした状態で読者の前に姿を表わす。それはまるで作 者が語り手の姿を借りて物語の中に登場するかの如くである。例文(1)“列 位"で始まるが、これは語り手の“我”が物語前面に登場し、読者に直接 語りかけている。以下文中の代名詞の指すものをまとめてみるが、これら 人称代名詞・再帰代名詞はすべて同一人物を示している。

它一从我骶骨那儿长出着的尾巴 


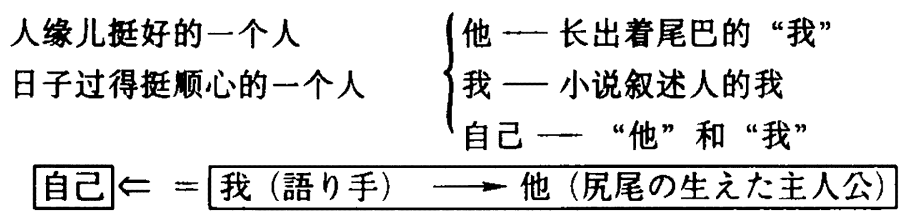

上記の表の矢印を視線と仮定すれば、物語の語り手はその視点を何処に 置くか、また視線を何処に向けるかで、一つのセンテンスの中で同一人物 を描写するにも、用いられる人称代名詞が変化する現象が理解出来る。人 称代名詞・再㷌代名詞の実際上の使用状況を明らかにするには、統語構造 からの考察に加え、梘点 (描写の方向) との関連も考慮する必要があるが、 後節にて検討する。

\section{1. 中国語・日本語・英語の再㷌表現}

中国語の再㷌表現"1は二つのタイブに分類される。

“自己” と“代名詞+自己”（我自己，你自己，他自己，我们自己，你们 自己，他们自己等)

英語の再㷌代名詞には以下のものがある。

単数 myself yourself himself herself itself oneself

複数 ourselves yourselves themselves

日本語の再帰表現 ${ }^{2} に$ に「自分」「自己」等がある。

従来、中国語の “自己”は英語の再帰代名詞と関連付け、統語規則の一 つとして多くの研究者によって取り上げられ、さまざまな議論がなされて きた。以下においてこれら表現形式の相違点を探ってみる。

\section{1 .}

英語の再㷌代名詞は、主節の主語とだけ照応関係を持つ日本語の再帰代 名詞「自分」とは違い、主節の主語と目的語のいずれとも照応関係を持つ ことが出来る。

久野 1973,191に以下のようにある。

(A) John talked to Bill about himself.

a. Johnは Bill に自分（= John）について話した。

b. JohnはBillに彼（=Bill）について話した。 
(B) 太郎八次郎ニ自分ニツイテ話シタ。

の「自分」は太郎を指すのであって、決して次郎を指すことにはなら ない。

程 1994, 35 に以下のようにある。

a. 老王不愿意同小李谈自己

“自己”只能受 “老王” 而不受 “小李” 的约束.

研究着们同意 “自己”有选择主语先行语的倾向, 但对其程度及成 因则意见分岐较大。

\section{2}

〈实用现代汉语语法〉1986, 47 に以下のようにある。

“自己”也可以泛指任何人。例如:

(a) 自己动手, 丰衣足食。

(b) 自己的事, 应该自己做, 不能依靠别人.

〈汉语八百词〉1999，695には「泛指句中未出现的某个主体」とあるが、 “类指用法”（generic use）といわれ、話し手にとり普遍の真理や事実を指 す用法がある。

下記例文の“自己”は上述したように広くあらゆる人を指す事が出来る。 (2) 其实想穿了, 就那回事儿, 实在不值得. 人哪, 说到底, 是自己 的目徒。(女)

(3) 你看, 事情就是这样, 明天你一枪把她崩了, 是合法: 要是今天你 打她骂她, 就叫虐待犯人, 就是违法的. 人类尽爱给自己找别扭. (女囚) (4) 仿佛冥冥之中真有一个主辛, 它若偏要按照它的意思演绎某个人的 命运，人自己是作不了自己的主的. (司马敦)

(5) 何かの職業に従事している教養のある者たちは、自分の教養を 示す必要のある機会毎に忘れず言葉を出すものだが、一旦話しが自 分の職業の危ない部分に触れてくると誰も話中から立って行く。(旅愁) (6) 自分の心の中に人間は一つは良い所があると思ってるものだよ。 それさえあれば、誰でも世界のものは、皆こんな心になってくれれ ば良いと願う一点があるのだ。(旅愁)

(7) 男も女も、自分が愛していれば、相手が同じぐらい爱していると 思いがちだし、自分が感心が薄ければ、相手もそれほど想っていな 
いと思ってしまうものですわ。(京都)

例文(2)(3)(4)の “自己”は人間全般を広く指している。例文(5)(6)(7)の「自 分」も「何かの職業に従事している教盖のある者たち」、「男も女も」或い は「人間」と不特定な人を指している。つまり中国語の“自己”・日本語の 「自分」は自分自身を意味する事も、他人を含めた広い範囲の人物を指すこ とも出来る事がわかる。

1.3

〈实用现代汉语语法〉1986, 47 に以下のようにある。

“自己” 有时可代替第一人称 “我”, 一般多用于较正式的口语。

(a) 领导的表扬对自己是一个旅策。

(8) 但自己是一名已经五十九岁的, 已经有整整四十年警龄的老刑警

啊！(司马敦)

(9) 别人是别人, 自己是自己阿 ! 人微言轻, 约束不了别人, 还约束不

\section{了自己么?（司马敦）}

中国語“自己”のこの用法は日本語の軍隊用語の自称詞としての「自分」 の表現とよく似ている。軍隊で上官に向かって話すとき兵隊は「私は…」 とは云わず、「自分は…等の表現をする。つまり上下の身分関係が確立し

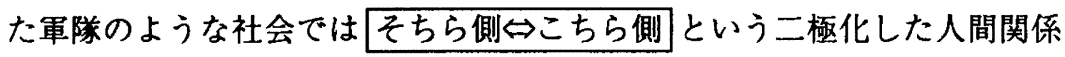
は存在しないため、このような現象が起こるのである。「私」のような自称 詞を用い相手@私といった対立した要素を会話の中に持ち込まず、相手 側の立場から見た「自分」つまり相手方に自分という人間の評価を委ねる ことから生じる、一つの相互関係である ${ }^{3)}$ 。英語の再帰代名詞には、以上 で述べたような用法はない。

\section{2.“自己”の敬語性}

木村 1990, 344-354 は三人称代名詞 'ta' の敬語制䄪について論じている が、再帰形式の “自己” は敬意を表す文脈では適応するのかどうか、以下 で検討する。

井上 1976,213に「自己」の敬語表現について記述がある。 


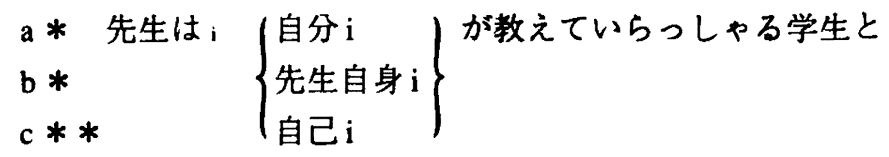

結婚したがっていらっしゃるよ。

それぞれに尊敬語の「ご」をつけると

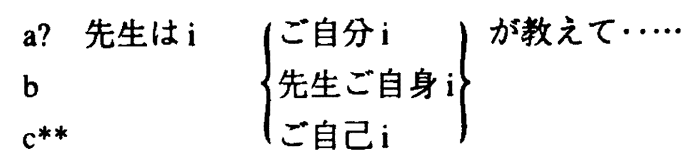

これらの例文から伺えることは、日本語の「自分」という再帰形式は、 敬語表現にはあまり適していないという事である。それでは中国語の再帰 代名詞“自己”は敬語表現に用いられるかどうかを考察してみる。

以下(10)〜(17)の例文は追悼文など4) あらたまった形式の文章から集めた ものである。その結果これらの文章で“自己”の使用は皆無ではないもの の、文章全体の割合からすると、その使用は極めて少ない事が確認された。

(10) 接任主编的那一年吕先生已是 73 岁高龄了, 他不辞辛苦、不惜牺 牲自己的研究时间, 为编出一本高水平的学术刊物和培养一个高水平 的编辑部，做了大量工作. (中国 1998, 3, 163)

（11）他在晚年总结自己的治学原则为 “强调广搜事例, 归纳条例, 反 对遮拾新寄, 游谈无根”. 这种扎扎实实做学问的严谨学风, 正是当 今我国学术界最需要的东西. (中国 1998, 3, 170)

(12) 他态度鲜明地支持语言学界反对不正之风的活动, 在倡议书上整 整地签上自己的名字。(中国 1998, 4, 284)

(13) 后来, 除了上测所坚持自己下床外, 吕先生已很难行动了.

(中国 1998, 4, 284 )

(14) 这样一位可亲可敬的九旬老人, 早已在中国和世界学术界享有极 为崇高的声望, 仍然一如既往, 以学术研究为自己的生命, 以弘扬中 国的语言学事业为自己的使命, 高山仰止, 不可及也.

(中国 1998, 4, 286)

（15）但他并不依恃常的记忆, 而是靠自己的极端勤奋.

(中国 1998, 4, 280)

(16) 先生的成就全凭自己的艰苦奋斗, 而他一生的信条就是 “力争上 
游”。( 中国 1999, 5, 351)

(17) 先生以自己切身的经验告诉我们怎样向他人学习:

(中国 1999, 5, 351)

例文(10)～(17)は何れも故人を偲ぶ文章で、著名な学者であった故人の業 績を称える文で“自己”が使われているら”しかしながらいずれの文章に おいても、故人を示す表現には “吕先生”“丁先生”などの使用が最も多 く、次いで用いられる三人称代名詞“ta” の使用状況と比較すると、“自己” の使用は極端に少ない。また上記例文(13)を除き、他の例文は“自己的生 命，自己的使命，自己的名字”など全て “自己的...”の形式である。これ らの状況から、中国語の“自己”は相手方に敬意を示す必要がある場面で は、その使用に一定の制約のあることがうかがえる。つまり木村 $1990,344-$ 354 “ta' 同様に、あくまで“自己”で示される人物がその場にいない、或 いは奻率性を求められる場合にのみ有効な表現でないかと考えられる6。 一般的に、追悼文は書き手・話し手自身の観点から、主体者である「故人」 の経験・経歴等を回想し述べるものであるため、客観的な同一性は確立し ていると言えるので、人称代名詞が用いられるのである。

井上1976,256に「報告文体」(reportive style) と「非報告文体」(nonreportive style）について言及があるが、日本語の「自分」の使用状況について、以 下の説明を参照されたい。

(a) ジョン i は、ビルが自分 $\mathrm{i}$ をめた時、メアリーのそばにいた。

(a) は「自分」が副詞節の中に現れ、主文の主語との照応関係を持

っている。この文は、主語の立場に立つ非報告文体では許される が、話者の立場に立つ報告文体では許されない。報告文体では(a) は(a)にならなければならない。

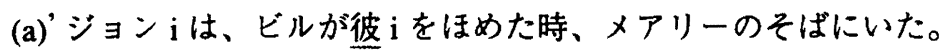

上記の説明に従い解釈すれば、追悼文で「故人」を意味する表現に“自 己”より“ta” の使用が多いのは、文章の性質上、主語の立場に立つ非報 告文体でなく、話者の立場からの報告文体の形式を取ることが多いためで もある。客観的な立場による記述が求められる状況では、再帰代名詞より 人称代名詞のほうが相応しく感じられる所以である。 
“自己”の敬語制約については、さらに細密な検討が必要であるが、本稿 では“自己”は敬意を表す文体でも用いられているということに止め、詳 しくは別稿で論じたい。

\section{3. 意識の想定}

中国語の再帰代名詞について、〈实用现代汉语语法〉1986，46に以下の ような説明があるが、ここで「原則 A」と定義する。

原則 A 当句子的主语代表施事者, 句中的宾语或宾语的修饰语又与 该主语相同时，一般来说，都不重复原主语的名词或代词，而用“自 己”.

以下は小説から引用した文章であるが「原則 A」に照らしてみる。

(18) …她不禁收紧肩胛，因为更捶心地意识到自己的穿着在这样的场 合不甚得体, 以及自己所用的化妆品所氮㬈出的气息不够高雅…(京) (19) 市长夫人认为自己是在跟一个精神出了毛病的人说话。（浮城）

(20) 我分明清楚地意识到自己是在娭妒她, 为什么我们需要的是同一 幅强有力的肩膀?! ( 杂症)

(21) 他对自己的失态着实吓了一跳, 望着陶星星那两只惊恐的大眼睛, 他有些后悔。（假）

(22) 她们几乎不相信自己的耳朵, 以为听错了. (司马敦)

(23) 他在心里暗暗提醒自己一 司马敦, 你怎么了？（司马敦）

例文(18) (23)はいずれも文中の主語が動詞の仕手であり、文中の目的語 或いは目的語の修飾語が主語と同じであるため、主語である名詞或いは人 称代名詞を繰り返さず“市长夫人, 我, 陶星星, 她们, 他” $\Rightarrow$ “自己”と なっており「原則 A」に抵触していない。

久野 1973,195に以下のような指摘がある。

a. 太郎八、自分ガ死又前ニ私ニソノコトタ打チ明ケタ。

* b. 太郎八、自分ガ死ンタ時、一銭モ持ッテイナカッタ。

(a)は太郎が死ぬことを自分で自覚していたという意味合いを含んで いる。恐らく太郎は自殺したか、死刑になったのであろう。他方(b) は非文法的である。私の仮説によれば(b)の非文法性は太郎が「私八 
死ンダ。と感じ得ないことに起因している。(中略)

a. 太郎八自分ヨ殺ソウトシテイタ男ヨ殺シタ。

b. 太郎八彼习殺ソウトシテイタ男

(a)はその男が太郎を殺そうとしていることを太郎自身知っていたこ とを意味しているが、(b)には、そのような意味合いが含まれていな い。太郎は知っていたかもしれないし、知らなかったかもしれない。 久野の主張をここで「原則B」と定義する。

原則 B 主文の名詞句 $\mathrm{A}$ を指して従属節 Bに現れる「自分」はAが Bによって表された動作・状態・出来事を意識している時にのみ文 法的である。

「原則 B」を例文(18)～(23)に当てはめると、“意识到，认为，吓了一跳， 不相信，提醒”など心理状態を表す動詞で、「原則 B」に適合している。

以下に挙げる文章は王力教授を偲ぶ追悼分の一段落である。木村 1990 , 344-354は三人称代名詞 'ta' の敬語制約において下記の文章を引用してい る。下線を施した部分に注目されたい。

(24) 王先生在遗嘱里说他对这一生是满意的。我想要是先生还有什么 遗惑的话, 恐怕就是 “文化大革命” 白白浪费了他十年时间。（略）

先生的逝世, 我自然十分悲痛, 可是想到先生一生写了那么多著 作, 又培养了那么多学生, 他的子女也各有专长, 能够自立, 又不禁 为他高兴。先生说他对他这一生是满意的。我能够理解先生的话。

( 语文研究, 1986, 3)

例文(24)下線を引いた文章を取り出し、人称詞に注目し検討してみる。 (24 a) 王先生在遗喝里说他对这一生是满意的。

(24b) 先生说他对他这一生是满意的。

それでは例文(24a)(24b)を「原則 $\mathrm{A} 」 に$ 照らし、以下のように改めるとど うであろう。

??(24 a)' 王先生在遗啒里 说自己对这一生是满意的。

$?(24$ b) 先生说他对自己这一生是满意的。

久野は「意識」或いは「内部感情」という概念が、再帰表現の使用に関 
係していると主張している。例文(24 a) を「原則B」に従い分析すれば“在 遗嘱里”という語句があるため、不自然な感じがする。「主語の意識が想定 されないなら、主語を “自分” の先行詞とできない」という原則に違反す るためである。例文(24 a) の状況のように、遺言書が外部に公表された時 点には、一般的にはそれを書いた人物はすでに亡くなっている。つまり遺言 書を書いた “王先生”は、遺言書が発表された時点には存命せず、すでに 意識の想定が不可能であるために“自己”との関係がしっくりしないので ある。一方例文 $(24$ b) は “先生”がまだ存命中に、先生が御自身の一生を 振り返り、他者に向かい「自分の一生は満足できるものである」と告げた と理解し、発話時点に先生の意識はあったと考えれば、(24a) ’り許容度 は高い。しかしながら文章全体の流れから、(24b)”は“在遗嘱里”の省略 されたものと判断できるため、この文脈で使われるのはやはり不自然であ る。

次の例文(25)を参照されたい。

(25) 记得一次探视时吕先生曾对我说: “我有时想, 我这一生多少做了 二点事情, 还是很幸福的。” 是的, 吕先生一生做的事情太多了, 他著 作等身, 研究领域涉及一般语言学理论、汉语语法 ( 从古到今)、文字 改革、语文教学、汉语对比、辞书编箱、古籍整理、乃至写作和文风 等等、将有 17 卷全集留给后世。他把自己的一切都献给了社会, 尽了 全部的心力, 他对自己的一生是满意的, 没有什么后悔, 也没有什么 遗㙳, 他确实是很幸福的。( 中国 1998, 4, 286 )

例文(25)網掛け部分の「他对自己的一生是满意的」は呂先生が生前に、自 らの人生を振り返り「我有时想, 我这一生多少做了一点事情, 还是很幸福 的」と語られた言葉を指している。

つまり先生がこの言葉を話された時点には、先生は「自分は人生に満足 している」という状況を意識出来る状態にあったので “自己”を用いる事 が出来るのである。

一方、例文(24a)(24b)は

先生 ( ) 说: “我对这一生是满意的。”

のような直接話法ではなく、先生が亡くなられた後、遺言書」を介し公開 
された情報である。人々は遗言春を通し、先生の「内的感情」“我对这一生 是满意的”を知り得たのである。遗言春の公開の時点には、先生の意識は 既にないため、例文(24a)(24b)で “自己”を用いるのは適当でない。「原則 B」の意識の想定についてはさらに細やかな分析が必要だと思われるが、 以下「視点」と関連し検討する。

\section{5. 視点と “自己”}

久野1987,66-68には以下のようにある。

(26) a. John $n_{i}$ hid the book behind himself ${ }_{i}$.

b. John ${ }_{i}$ hid the book behind him ${ }_{\mathrm{i}}$.

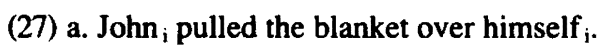

b. John ${ }_{i}$ pulled the blanket over him $\mathrm{i}_{\mathrm{i}}$ （中略）

Semantic Constraint on Reflexives (revised) :A[+reflexive]NP that ends with -self / selves can be used in English if and only if its referent is the direct recipients or target of the actions or mental states represented by the sentences.

Kuno 1987 は例文(26)(27)(a/b)の違いは「意図的・意識的」対「偶発的・無 意識的」という意味の違いがあるとしている。(26a)はジョンが本を手に持っ てそれを背後に隠したという含意があり、この時、本は直接彼と接触して いる。一方(26b)は本がたとえば椅子の上にあり、彼が立ち上がったため、 その本が彼の後ろに隠れてしまったという含意が考えられる、としている。

澤田 1993,301 は「原則B」について「主文の名詞句Aが従属節の内容 (内部感情)を意識しているかどうかという条件は、形式的な条件とは性格 を異にし、認識的 ·心理学的な色彩を带びており、意味論的にもきわめて 興味深い観察となっている。」としながらも、再㷌表現に関する現象を、す べて視点の観点からとらえ「(26a)は主語のジョンの側からその行為をとら え、(26b)は話し手の側からその行為をとらえている。と解説している。澤

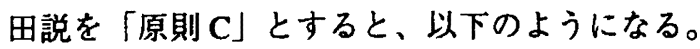

原則C ある単文において、先行詞が主語であり、それによって束 縛される代名詞／再㷌代名詞が文の中に存在する時、再帰代名詞が 現れている場合にはその行為は主語の側から描写されており、代名 
詞が現れている場合にはその行為は話し手の側から描写されている。

しかしながら筆者は例文(26)(27)は「原則B」に従い、従属節にあらわれ る再帰形式は先行詞の主語の「意識」に関係していると理解し「例文(26a) (26b)は主語のジョンが意識的に行った行為で、(26b)(27b)はジョンが無意識 に行った行為である」と視点と意識の両面から解釈した方が良いのではと 考える。すなわち「原則 B」で取り上げられた意識の有無は「原則 C」の 視点とともに、文脈に扔ける代名詞・再帰代名詞の選択に大きく関係して いると考えられる。

澤田 1993, 302 は「原則 B」を否定し、代名詞・再州代名詞の問題をすべ て視点に基づくものと解釈し、以下のような反論を述べている。

(28) 太郎 ${ }_{\mathrm{i}}$ はその日が [自分 ${ }_{\mathrm{i}}$ の誔生日であることを] すっかり忘れ ていた。

(29) 僕 ${ }_{\mathrm{i}}$ は [自分 ${ }_{\mathrm{i}}$ が優勝できるなんて］夢にも思わなかった。

澤田の疑問は、例文(28)(29)では主語が補語の内容を知らなかったり、理 解できなかったり、意識していなかったりしたことが述べられているのに、 なぜ適格文とされているかの点にある。澤田はこれらの現象の解釈に以下 のような説を提示している。この説をここで「原則D」とする。

原則D 日本語の複文において、主節の行為・感覚の主体が先行詞 で、それが束縛する代名詞／再㷌代名詞が従属節に存在する時、視 点が話し手の側にあれば代名詞が、先行詞の側にあれば再帰代名詞 が選ばれる。

以下の例文(30)は小説登場人物の「彼女」が記憶を失い、その失われた記 憶を搜し求めていた様子を述べた文章である。

(30) 彼女は、自分が、どこに勤めていたか、どこに住んでいたかも わからないので、毎日、いろいろな電車に乗ってみたんだといって いましたわ。（環状線に消えた女）

中国語ではどうか、以下に中国語の具体例を挙げてみる。

(31) 陆明也想不出她怎么会打动自己, 一不出群, 二不艳丽, 那种 极典型的黄皮肤，谁也不会怀疑她的列祖列宗是中国人。(假)

(陸明はどうして彼女がこれほど自分の心を摇さぶるのか考えつかな かったい) 
（32）陶星星也 不知道自己怎么会这么平静自若地撒慌。（假）

(陶星星にも自分がどうしてこんなにも平然と嘘がつけるのかわから なかった。)

(33) 楮少良怎么也想不出 自己究竟犯下了什么过失, 他们为何将他 带到这里. (雨季)

（裙少良は自分が一体どんな過ちを起こしたのかわからなかった．.）

例文(31)～(33)は澤田の主張と同じく、主語が補文の内容を知らなかった ク、意識していなかったりして、すべて「原則B」に反しているが、文法 的には適格文である。「原則B」のどこに問題があるか、以下の例文を検討 してみる。

(34) 这一天午后一点十五分, 敬爱的吕叔湘先生走完了他九十四年的 人生旅途, 在沉睡中安静地离开了我们. (中国语文 1998, 3 )

例文(34)“他”を“自己”に書き改めると、どうであろう。

?(34) 这一天午后一点十五分, 敬爱的吕叔湘先生走完了自己九十四 年的人生旅途, 在沉睡中安静地离开了我们。

この文章は“吕叔湘先生”が亡くなられたことを読者に報告している。 「原則C」は話し手の視点が先行詞にあれば再帰形式が用いられるとしてい るが、この場合主語である “吕权湘先生”はすでに亡くなられているため、 先行詞である先生の視点にたつことは不可能である。故に例文(34)で再帰表 現を用いるのは適当でない。このように先行する主体がすでに事態を意識 することが出来ない状態では、再帰表現を用いるのは適当でない。この問 題は例文(24)においても言及した様に、主体者 (先行詞) が意識することが 不可能な状態では、視点を主体者に置く事は出来ないため、再帰形式は一 般的に用いられない。

\section{5. まとめ}

代名詞·再㷌代名詞の原則を文文法で説明するのには有効な手段である。 しかしながら文文法のレベルにおいて、代名詞と先行詞の照応関係がすべ て解決出来る訳でない。様々な現象を説明するには、他の要素つまり意味 論・語用論的立場からの分析が必要である。 
文学作品の文章は、現実の言語にすでに存在する規則に基づき、それを 意図的に・技巧的に拡大している。そのように意図的に拡大された要素は 色々な問題を発見する良い手がかりを与えてくれる。本稿文頭に挙げた小 説の一段落は、代名詞・再帰代名詞の使用には「視点」が関係することを 示してくれた。本稿は中国語・日本語・英語の再帰形式の原則を取り上げ、 各言語の枠を超えやや強引に適応させてみた。その結果「梘点」は「意識」 とともに、中国語の再帰形式の使用状況に緊密な関係のあることが確認さ れた。

\section{〈注〉}

1）程工 1999, 33:「汉语中的“自己” 不是纯粹的反身代词，而是由一个反身代词和 一个泛指代词构成的复合词.」としているが本稿では言及しない。

2）井上 1976,203に「自己」「自分」および名詞に「自身」または「自体」がつい た形式を再帰名詞と総称し「自分」「自己」「自身」「自体」を再穆形式と呼んでいる。 日本語の再㷌形式は、英語の様に人称代名詞 + self と形が一定し、人称代名詞の 部分が中心となって、人称・数・性による一定の語形変化をするということがない。 また、「自身」と「自体」は、広く固有名詞、普通名詞、代用名詞と結合して再㷌 名詞を作る。日本語では、代用名詞も独立の筑略を作らず、名詞の一部と考えら れる。再㷌代名詞ではなく、再㷌名詞の名称を使うのは、この理由からである。」 とあるが本稿では再帰代名詞という用語を用いる。

3）田洼 1997,36に軍隊用語の「自分」について「この「自分」は直示ではなく話 し手の領域においても值解积をされるだけなので待遇性を持たない。待遇的な人 称名称のように、対称詞との対による人間関係を持ち込まず、いわば間接的な自 己指示をすることができるからである。とある。

4），沉痛婥念吕叔湘先生，r一代宗师，风范永存，r哭吕先生，r吕叔湘先生生平， '我国著名语言学家吕叔湘先生逝世, $r$ 永远的还念, $r$ 遥寄哀思, $r$ 一代宗师的学者 风范, '吕叔湘先生与青年一代, '勤奋 实在 光博 创新 严谟纪念丁声树先 生,‘丁声树同志的治学精神,‘纪念常培师。など計 12 篇。

5）筆者の手元には以下のような例文があるが、本稿では “人称詞＋自己”の形式 についてはふれない。

㗊先生自己做了一辈子学问, 取得了那么高的学术成就, 在国内外享有崇高的 声㷛, 但他更关心的是整个语言学事业在中国的发展前途, 倾注许多心血来培养下 一代，殷切地期望他们早日脱颖而出。(中国 1998, 3, 166)

吕先生让我重点从王力先生《汉语史稿》中册、太田辰夫先生《中国语历史文 
法》、他自己的《汉语语法论文集》以及丁声树先生的几篇古汉语论文中体会研究 方法. (中国 1998, 4, 284)

6）木村 1990,352

与实在的指标对象的接触较为间接或疏远的情况下，对尊长人物使用敬语称谓 的必要性减少，经济性原则优先的倾向则增加，从而较易使用 ' $\mathrm{ta}$ '.

\section{《参考文献〉}

程工 1994.「生成语法对汉语“自己”一词的研究」，「国外语言学」第 1 期, 34-40页。 一 1999. 「汉语 “自己”一词的性质」, 「当代语言学」第 2期, 33-43 页。 井上和子 1976. 「変形文法と日本語（下）一意味解釈を中心に」大修館萻店。 刘月华·潘文娱·故㱖 1986(1983). 「实用现代汉语语法」。外语教学研究出版社。 木村英榯 1990. 「设语第三人称代词敬语制约现象的考察」，「中国语文」第 5 期, 344-354 页。

久野睡 1973. 「日本文法研究」。大修館春店。

(Kuno, S) 1987. Functional Syntax. The University of Chicago Press.

澤田治美 1993.「視点と主钼性一日英語助動詞の分析」。ひつじ書房。 田寉行則 1997. 「日本語の人称表現」，「視点と言語行動」くろし扔出版。 田洼行則・木村英㣥 1992. 「中国語，日本語，フランス語における三人称名詞の対 照研究」、日本語と中国語の対照研究論文集 (上)」。くろしお出版。 吕权湘主编 1999(1987). 「现代汉语八百词」。商务印书馆。

\section{<用例出典 >}

梁晓声「尾巴」「荒野作证」。长江文艺出版社 1997。

「司马敦」「荒野作证」。长江文艺出版社 1997。

「浮城」。花城出版社 1992 。

张欣（假）「假如能够重新选择」「然烧岁月」。群众出版社 1996。

「杂症」「然烧岁月」。群众出版社 1996。

陈劲松（女）「女四」「收获」2000年第 5 期。

刘心武 (京)「京漂女」「当代」2001。

格非 (雨季) 「雨季的感觉」。人民文学出版社 2000 。

「语文研究」「悼念王力师」1986 年第 3 期。

(中国)「中国语文」「沉痛婥念吕叔湘先生」1998 年第3期。

一个一代宗师，风范永存」1998 年第 3 期。

「哭吕先生」1998 年第 3 期。

一遥寄哀思」1998 年第 4 期。

一个永远的还念」 1998 年第 4 期。 
横光利一【旅愁」。新潮社 1967 。

山村美紗 (京都)「京都・神戸殺人事件」。光文社 1988。 西村京太郎「環状線に消えた女」。中央公論社 1987。 